\title{
E-NAM PLATFORM: A HAND TO SURVIVE INDIAN AGRICULTURE FROM COVID19 OUTBREAK
}

\author{
Professor Renu Jatana ${ }^{1 \rrbracket}$, Mohit Goswami ${ }^{2} \square$ (iD) \\ ${ }^{1}$ Former Dean \& Professor, UCCMS, MLSU, India \\ ${ }_{2}^{2}$ Junior Research Fellow, UCCMS, MLSU, India
}

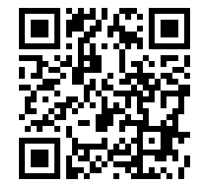

Received 28 November 2021

Accepted 10 December 2021

Published 31 January 2022

\section{ABSTRACT}

Coronavirus, also known as COVID19, was an unprecedented shock for the Indian economy, already in the vulnerability stage. With the prolonged country-wide lockdown, the Indian economy downturn. COVID19 had stuck almost all the sectors of the economy, but the agriculture sector had managed to survive in the COVID19 outbreak with the help of the Central Government scheme, namely the eNAM platform. This study aimed to evaluate the spread of COVID19 in India, the current status of the eNAM platform and its growth. In contrast, the study also focused on comparing the total commodity arrival of the eNAM integrated market during the COVID19 period with the previous period. The study had selected April 2020 to March 2021 as a COVID19 period and April 2019 to March 2020 as the last period; for comparison study had selected the Fathenager eNAM market as a sample. The particular research had applied the CARG model to evaluate the growth of eNAM markets, whereas for hypothesis testing implemented Chi-square test. eNAM had significantly increased growth by $84.8 \%$ in the last four years by integrating 1000 APMC markets with the eNAM platform.

\section{CorrespondingAuthor \\ Mohit Goswami, \\ goswamimohit83@gmail.com}

\section{DOI 10.29121/ijetmr.v9.i1.2022.1103}

Funding: This research received no specific grant from any funding agency in the public, commercial, or not-for-profit sectors.

Copyright: (C) 2022 The Author(s). This is an open access article distributed under the terms of the Creative Commons Attribution License, which permits unrestricted use, distribution, and reproduction in any medium, provided the original author and source are credited.

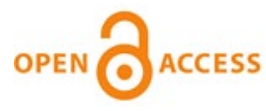

Keywords: COVID19, Impact, eNAM, Growth, Indian Economy, and Agriculture Sector

\section{INTRODUCTION}

The World was witnessed several epidemics, for instance, the Spanish flu of 1918, SARS (Several Acute Respiratory Syndrome) in 2003, Swine flu in 2008 and Ebola. Simultaneously, the World is now facing the Coronavirus, popularly known as the COVID19 pandemic, SARS-CoV-2. COVID19 was originated in Wuhan, China, in December 2019 and, over the next few months, quickly spread to almost all the worldwide nations, which can potentially turnout to be the most significant health crisis in history. In India, COVID19 started spreading in March 2020, but India's first case of COVID19 was on 30 January 2020 in the state of Kerala.

India has made an early move to constrain the spread of COVID19, requesting a 21-day across the country lockdown for its population of 130 crores beginning from 25 March 2020; as a result, the epic Coronavirus has spread generally in India moderately low as compared to other nations in 1st layer of Coronavirus. But in the 2nd layer of Coronavirus, India is the 2nd most infected country with 2.93 crores confirmed cases (till 12 June 2020) in the World, following by the United States with 3.34 crore confirmed cases (till 12 June 2020) and followed by Brazil, France, and Turkey with 1.72 crores 
57.3 lakhs and53.2 lakhs confirmed cases (till 12 June 2020) which is primarily because of negligence and carelessness people resident in-country for instance not wearing a mask, not maintaining social distancing and ignorance of health issues etc.,

The COVID19 outbreak has taken the World completely unaware, exposing the vulnerability of the agricultural system along with public health in coping with these pandemics. India is the World's agricultural powerhouse, the largest producer of milk, pulses, and spices, and has the World's largest cattle herd and the most significant area under wheat, rice, and cotton. The pandemic wreaked substantial physical, social, economic, and emotional havoc on all the stakeholders of the Indian agricultural system.

The government of India has announced various packages and schemes to survive and overcome Coronavirus in the different sectors, including the agriculture sector, for instance, the COVID19 social assistance package of INR 1.7 lakh crore, which is almost 25 billion US\$ under Pradhan Mantri Garib Kalyan Yojana (PM-GKY) to provide benefits to farmers and rural household, or government price stabilization policies helped stability in cereal prices initially, and prices of essential commodities remained stable in May\& June 2020 due to better supply chain management. The schemes announced in light of Coronavirus and schemes like eNAM (Electronic national agriculture market) have become a helping hand to cure the impact of COVID19 on the agriculture sector.

eNAM portal is a scheme of the Government of India to integrate APMC (Agriculture Producer market committee) markets and create a unified national market by virtual network formation all over the nation to build the "ONE NATION ONE MARKET", which was announced on 14 April 2016. It is a program of liking markets with a colossal effort of many agencies involved like the central government, which provides a uniform policy framework, Small Farmers Agribusiness Consortium (SFAC) playing the role of the lead agency along with private strategic partner Nagarjuna Fertilizers and Chemicals Limited for maintenance of the portal, Directorate of Marketing and Inspection (DMI) for providing technical support for harmonization of standards for commodities and assaying facilities, National Information Centre (NIC) for providing necessary servers to host e-NAM portal, state governments and marketing boards providing storage and warehousing facilities, regulate and dispute resolution mechanism to APMC markets, and APMC markets for implementation of physical and online trading.

In the meantime, of COVID19 outbreak where all the sectors shut down due to control the spread of infection, The Government of India has permitted the farmers to straight sell their produce from selected warehouses or premises of farmers producer organizations (FPO) over electronic marketing platform eNAM, completely bypassing the Market. eNAM portal help farmers access the information through their mobile phones from anywhere. eNAM is helping farmers to trade their products through the virtual network using mobile applications to earn a survival benefit. The government also allowed registered farmers to appoint the eNAM markets to assassinate crops and permit them to sell products directly from the warehouses.

\section{OBJECTIVES OF STUDY}

1) To evaluate the spread of COVID19 in India.

2) To check the current status of eNAM in India. 
3) To Study total commodity arrival from April 2018 to March 2020 of eNAM integrated market in Rajasthan.

4) To compare commodity arrival during COVID19 outbreak with the previous period for selected eNAM Market.

\subsection{HYPOTHESIS OF STUDY}

Ho(1) $=$ There is no significant difference in selected commodity arrival during the COVID19 outbreak compared to the previous period.

\section{REVIEW OF LITERATURE}

A literature review is a survey of scholarly materials on a given topic. It provides an overview of current knowledge, helping you to discover pertinent ideas, techniques, and gaps in the available research. Below reviewed literature to find a gap in particular study.

Sahoo and Samal (2020) In this paper, "Impact of Covid-19 on Indian agriculture", the authors were aimed to evaluate the impact of Covid-19 on Indian Agriculture. The study was descriptive, based on secondary sources of data. Authors had stated six effects of Covid-19. First visible results of Covid-19 on rural supply chain, the second impact was the put off in sowing and harvesting plants, predicted the third effect task cuts in the agriculture, the fourth massive impact was the complete shutdown of exports, the fifth effect was on MSME's \& SMEs, and the sixth effect was the prediction of a weak consumption trend post-Covid-19.

Chetan and Yogesh (2020) The particular paper, "Covid-19 impacts on the Indian Agriculture, " focused on analyzing the impact of Covid-19 on Indian Agriculture. This research is primarily descriptive based on Secondary sources of data. Secondary data has been collected from different published sources like books, journals, newspapers and magazines, and websites. It can be concluded that the food supply chain had been hit the strongest by the pandemic, resulting in a shortage of food security amongst the most vulnerable segment of the population. Apart from that, if we run deeper, we will observe that the migrant labour or crisis directly affects the agricultural sector employment.

Arumugam et al. (2020) In this paper, "Covid-19: Impact of Agriculture in India," the authors objective was to evaluate the impact of Covid-19 on Indian agriculture. The progressing wellbeing emergency around COVID-19 has influenced varying societies. Governments have swung into activities since the Coronavirus assault made an extraordinary circumstance. Rules gave by the Ministry of Home Affairs, Government of India on 15 April 2020 after the expansion of lockdown till 10 May 2020, excluded agribusiness, agriculture, creature farming, poultry, and fishery, and partnered exercises from lockdown limitations; workers can go to work, markets are to open, acquirement is to occur, and Agri-input shops and agrohandling focuses are to work.

\section{MATERIALS AND METHODS}

The particular study employed empirical research design and based on secondary sources of data which was collected from various sources which are elaborated in the below table: 


\begin{tabular}{|c|c|c|}
\hline \multicolumn{3}{|c|}{ Table 1 Sources of Data } \\
\hline DATA & Website & Source \\
\hline $\begin{array}{l}\text { Covid-19 } \\
\text { confirmed } \\
\text { Patient }\end{array}$ & $\begin{array}{l}\text { Ministry of Health and } \\
\text { Family Welfare } \\
\text { website and } \\
\text { Organization website }\end{array}$ & $\begin{array}{l}\text { https://www.mohfw.gov.in and } \\
\text { https://www.covid19india. org/ }\end{array}$ \\
\hline $\begin{array}{l}\text { Number of } \\
\text { eNAM market } \\
\text { in India }\end{array}$ & $\begin{array}{l}\text { Electronic National } \\
\text { Agriculture Market } \\
\text { Website }\end{array}$ & $\begin{array}{l}\text { https://enam.gov.in/web/e } \\
\text { Nam-market-status }\end{array}$ \\
\hline $\begin{array}{l}\text { Stakeholder } \\
\text { of eNAM in } \\
\text { India }\end{array}$ & $\begin{array}{l}\text { Electronic National } \\
\text { Agriculture Market } \\
\text { Website }\end{array}$ & $\begin{array}{l}\text { https://enam.gov.in/web/dashboard/stakeholder- } \\
\text { data }\end{array}$ \\
\hline $\begin{array}{l}\text { Total arrival } \\
\text { of product in } \\
\text { eNAM market }\end{array}$ & $\begin{array}{c}\text { Ministry of } \\
\text { Information and } \\
\text { Broadcasting } \\
\text { (Government of India) } \\
\text { DgMarket website and } \\
\text { Department of } \\
\text { Agriculture market } \\
\text { (Government of } \\
\text { Rajasthan) }\end{array}$ & $\begin{array}{c}\underline{\text { https://agmarknet.gov.in/D efault.aspx and }} \\
\text { http://market.agriculture.raj } \\
\text { asthan.gov.in/Default.aspx }\end{array}$ \\
\hline
\end{tabular}

The target of the study is to evaluate the peak and increment of confirmed cases at the national level with the possible measures taken by the Government of India and other state governments. The study also analyses the current status of the eNAM network and growth at the national level, whereas to evaluate the impact of COVID19 on agriculture production, a comparative analysis has been conducted on total arrival of a commodity during COVID-19 with the previous period for which April 2020 to March 2021 consider as COVID-19 period and April 2019 to March 2020 view as last period.

For comparative analysis, Fathenager Market has been selected because it has been integrated with the eNAM platform from the day the first scheme was launched. The study focuses on four significant commodities that have the highest arrival during the COVID-19 period: Wheat, Maize, Jawar and Bengal Grams, out of which Wheat and Bengal Grams are rabi crops whereas Maize and Jawar are Kharif crops.

In the particular study, to present data visualization tables, figures and diagram has been employed which includes Bar, Column and map chart using MicrosoftExcel and Tableau v2020 whereas for analysis various test has been applied using SPSS v24 which are as follows:

\subsection{NORMALITY TEST}

A distribution plot of the collected data is helpful to check the normality of the data. The data distribution should be restricted to determine that it does not deviate too much compared to the normal distribution. To ensure the normality of data Kolmogorov-Smirnova test and Shapiro-Wilk test was employed, and it was found that data was not normally distributed, or data was non-parametric in nature. 


\subsection{CHI-SQUARE TEST}

The Chi-square test of homogeneity determines if two or more independent samples vary by distributions on a single variable. A common use of this test is to compare two or more groups or conditions on a categorical result. Karl Pearson propounded the Chi-square test in 1900.

\subsection{CAGR MODEL}

CAGR stands for Compound annual growth rate. It measures a yearly growth rate over time, with the effect of compounding taken into account.

\section{RESULTS AND DISCUSSIONS}

\subsection{STATUS OF COVID19 IN INDIA AND GOVERNMENT MEASURES}

Global pandemic COVID19 inflecting health of people and had taken economy of countries into shock. As the nature of decease is highly contagious and to contain the spread of decease, the government had imposed policy action such as the imposition of social distancing, mask, restriction on mobility, self-isolation and even closure of institute at the earlier stage of Covid-19 but as the confirmed cases increase government had imposed lockdown of an entire country. Alarming for Covid19 as the Government of India requested a 14-hour national curfew on 22 March 2020, named "Janata Curfew". To curb the spread of Covid-19, the Government of India had imposed a lockdown of an entire country in 4 Phases, and this unprecedented lockdown has harmed the economy. 1st Phase was imposed from 24 March 2020 to 14 April 2020. In this duration, Finance Minister Nirmala Sitharaman had announced a ₹ 170,000 crore stimulus package, whereas the Reserve Bank of India announced a slew of measures to help mitigate the economic impacts of the lockdown. As an extension of lockdown, the Government of India has imposed lockdown in 3 phases from 15 April 2020 to 3 May 2020, 4 May 2020 to 17 May 2020 and 18 May 2020 to 31 May 2020.

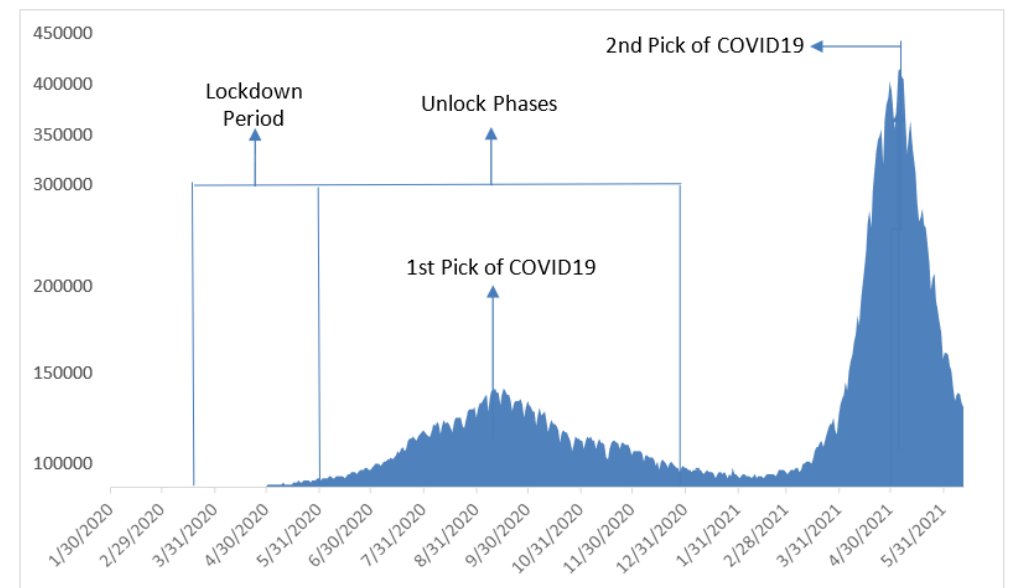

Figure 1 Showing Status and Pick of COVID19 as well as Lock-Unlock Phases 
The government of India had started the phases of unlocking in the focus of the economy. Unlock has 6 phases starting from 1 June 2020 to 30 November 2020. After the $6^{\text {th }}$ Phase, the Government of India had removed restrictions majorly but had decided to resume educational institute from January 2021 and international flights after 31 January 2021. As the unlocking process started, the Number of confirmed cases has increased, and as a result, India had touched the first pick on 16 September 2020 during the $4^{\text {th }}$ unlocking Phase with 97,860 confirmed cases.

India was getting back on track of economic growth from Covid-19, but with time, India hit back with Covid-19 Second layer, which was more dangerous and contagious than the first layer. The second layer was stated from March 2021 to now. On 5 May 2021, India had touched the $2^{\text {nd }}$ pick of Covid-19 with 4,12,624 confirmed cases. Covid-19 hit the country's economy as never before as all the sectors of the economy faced backdrop and making loss while agriculture sector seemed to be growing compared to the previous year because of high productivity. To develop and survive of agriculture sector during the Covid-19, eNAM has become a shield to the agriculture sector from the impact of Covid-19.

\subsection{ELECTRONIC NATIONAL AGRICULTURE MARKET (eNAM) \\ 5.2.1. CURRENT STATUS OF ENAM AT THE NATIONAL LEVEL}

eNAM is an integrated platform of APMC markets that provides all the information regarding total arrivals of commodity, real-time market price buys and sells trading offers and its response and other services through the user-friendly mobile application. Totally 415 more markets are integrated by May 2020, and the Government of India planning to link all Market with the e-NAM platform by 2022. So far, 1000 markets across 18 states and 3 UT's have been integrated. On 20 June 2019 Government of India had launched e-NAM Version 2.0. It regulates continuous material flow through virtual online Market and reduces transaction costs and information asymmetry.

\begin{tabular}{|c|c|c|c|c|c|c|c|}
\hline \multirow{3}{*}{$\begin{array}{c}\text { S. } \\
\text { No. }\end{array}$} & \multirow[t]{3}{*}{ State and UT's } & \multicolumn{6}{|c|}{ APMC's } \\
\hline & & \multirow{2}{*}{$\begin{array}{l}\text { Pilot } \\
\text { Phase }\end{array}$} & \multirow{2}{*}{$\begin{array}{l}\text { PhaseI } \\
\text { (Sep201 } \\
\text { 6) }\end{array}$} & \multicolumn{2}{|c|}{ Phase II } & \multirow{2}{*}{$\begin{array}{l}\text { PhaseIII } \\
\text { (March } \\
\text { 2018) }\end{array}$} & \multirow{2}{*}{$\begin{array}{c}\text { PhaseIV } \\
\text { (May } \\
\text { 2020) }\end{array}$} \\
\hline & & & & $\begin{array}{c}\text { (March } \\
\text { 2017) }\end{array}$ & $\begin{array}{c}\text { (May } \\
\text { 2017) }\end{array}$ & & \\
\hline 1 & Andhra Pradesh & - & 12 & 22 & 22 & 22 & 33 \\
\hline 2 & Chandigarh & - & - & - & - & 1 & 1 \\
\hline 3 & Chhattisgarh & - & 5 & 14 & 14 & 14 & 14 \\
\hline 4 & Gujarat & 3 & 40 & 40 & 40 & 79 & 122 \\
\hline 5 & Haryana & 4 & 37 & 54 & 54 & 54 & 81 \\
\hline 6 & $\begin{array}{l}\text { Himachal } \\
\text { Pradesh }\end{array}$ & 2 & 7 & 19 & 19 & 19 & 19 \\
\hline 7 & Jharkhand & 1 & 8 & 19 & 19 & 19 & 19 \\
\hline 8 & $\begin{array}{l}\text { Jammu } \\
\text { \&Kashmir }\end{array}$ & - & - & - & - & - & 2 \\
\hline 9 & Karnataka & - & - & - & - & - & 2 \\
\hline 10 & Kerala & - & - & - & - & - & 6 \\
\hline 11 & Madhya Pradesh & 1 & 20 & 50 & 58 & 58 & 80 \\
\hline
\end{tabular}




\begin{tabular}{|c|c|c|c|c|c|c|c|}
\hline 12 & Maharashtra & - & - & 15 & 45 & 60 & 118 \\
\hline 13 & Odisha & - & - & 10 & 10 & 10 & 41 \\
\hline 14 & Puducherry & - & - & - & - & 2 & 2 \\
\hline 15 & Punjab & - & - & - & - & 19 & 37 \\
\hline 16 & Rajasthan & 1 & 11 & 25 & 25 & 25 & 144 \\
\hline 17 & Tamil Nadu & - & - & - & - & 23 & 63 \\
\hline 18 & Telangana & 5 & 44 & 44 & 44 & 47 & 57 \\
\hline 19 & Uttarakhand & - & - & 5 & 5 & 16 & 16 \\
\hline 20 & Uttar Pradesh & 6 & 66 & 100 & 100 & 100 & 125 \\
\hline 21 & West Bengal & - & - & - & - & 17 & 18 \\
\hline & Total & 23 & 250 & 417 & 455 & 585 & 1000 \\
\hline & R Coefficient & \multicolumn{6}{|c|}{1.848} \\
\hline & Growth & \multicolumn{6}{|c|}{$84.80 \%$} \\
\hline & gn. Value & \multicolumn{6}{|c|}{0.005} \\
\hline
\end{tabular}

Source: eNAM Website

In a pilot survey, 23 APMC markets were integrated with the eNAM platform and with the successful implementation, the Government of India had increased the integration process from time to time. With the help of the CAGR Model, it was found that the coefficient of compounding was 1.848 and growth was $84.8 \%$ with a significant value of 0.005 , which is less than 0.01 at a $1 \%$ level of significance. It is statistical proof of significant growth in eNAM markets in the last four years.

The e-NAM system was implemented in Rajasthan with its initial launch in April 2016 in 8 states across the country. As of May 2020, 144 Markets were connected through e-NAM in Rajasthan. Out of 144 Markets, 1 Market have been integrated into a pilot phase, whereas more than 10 Markets have been integrated into 1st Phase of e-NAM and the rest in the next Phase.

\subsubsection{TOTAL ARRIVAL OF COMMODITIES IN THE ENAM MARKET OF RAJASTHAN}

During the Covid-19, where all the sectors hit back, the agriculture sector was seemed to be survived and make growth in the second and fourth quarter of 20202021 (Covid-19 period) as the total arrival of eNAM markets was 9056349.27 quintals and 19939320.98 quintals, respectively, in this period which was more than total commodity arrival of eNAM markets in pervious year second (7568513.98 quintals) and fourth quarter (12509174.17 quintals). 


\section{(In Quintals)}

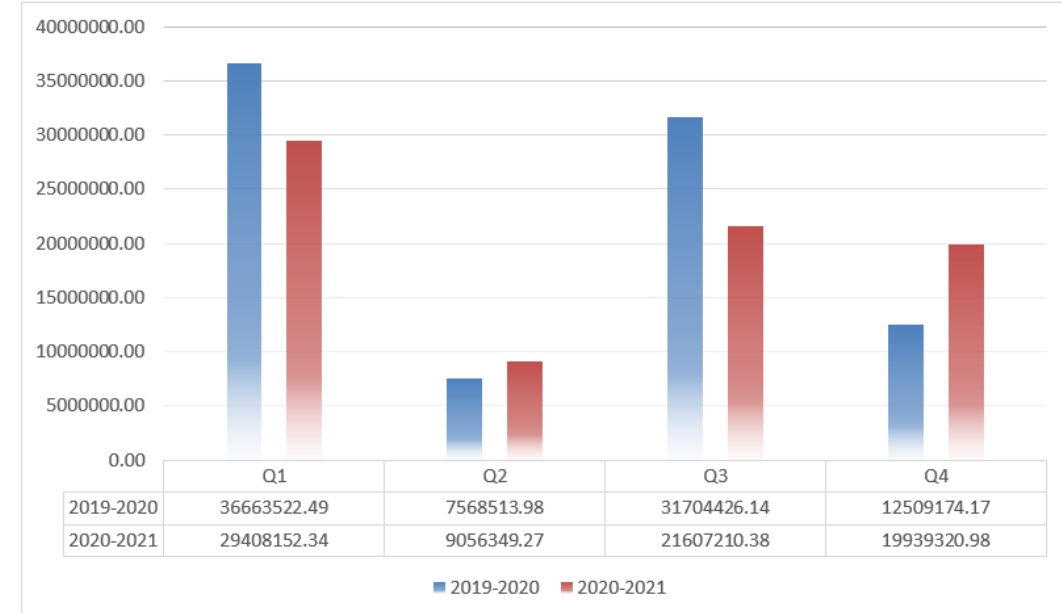

Figure 2 Showing total commodities arrival in eNAM markets of Rajasthan from April 2019 to March 2021 (Quarter-wise)

At the starting spread of Covid-19 in India, the Total commodity arrival of eNAM markets for the first quarter (29408152.34 quintals) was less than the previous period total arrival (36663522.49 quintals), whereas, during the third quarter when India was facing pick of confirmed cases of Covid-19, the total commodity arrival of eNAM markets was 21607210.38 quintals which were again less than previous period total arrival, i.e., 21607210.38 quintals.

\section{HYPOTHESIS TESTING}

$\mathbf{H o}_{\mathbf{1}} \mathbf{1}=$ There is no significant difference in selected commodity arrival during the COVID19 outbreak compared to the previous period.

The particular study was aimed to evaluate the effectiveness of eNAM to protect the agriculture market from the impact of Covid-19 by comparing total arrival during Covid-19 with the previous period, for which the Fathenager eNAM market with four major commodities was selected. Wheat, Maize, Jawar and Bengal Grams was the major commodity arrival in the Fathenager eNAM market. In 2019-2020, the Average arrival of Wheat, Maize, Jawar and Bengal Grams was 7219.75, 4852.33, 592.16 and252.33 quintals, respectively, whereas, in 2020-2021, the average arrival of Wheat, Maize, Jawar and Bengal Grams was 9840.41, 18502.08, 1385.58 and 963.83 quintals, respectively.

\section{(In Quintals)}

\begin{tabular}{|c|c|c|c|c|c|c|c|c|}
\hline \multirow[t]{3}{*}{ Month } & \multicolumn{2}{|c|}{ Wheat } & \multicolumn{2}{|c|}{ Maize } & \multicolumn{2}{|c|}{ Sorgham (Jawar) } & \multicolumn{2}{|c|}{$\begin{array}{l}\text { Bengal Grams } \\
\text { (Chana) }\end{array}$} \\
\hline & 2019- & 2020- & 2019- & $2020-$ & 2019- & 2020- & 2019- & 2020 \\
\hline & 2020 & 2021 & 2020 & 2021 & 2020 & 2021 & 2020 & 2021 \\
\hline April & 14182 & 28031 & 588 & 4677 & 17 & 67 & 1116 & 3270 \\
\hline May & 15632 & 29073 & 189 & 1306 & 98 & 60 & 794 & 1402 \\
\hline
\end{tabular}


Renu Jatana, and Mohit Goswami

\begin{tabular}{|c|c|c|c|c|c|c|c|c|}
\hline June & 11302 & 25912 & 262 & 3079 & 219 & 116 & 281 & 2543 \\
\hline July & 15298 & 12953 & 515 & 3211 & 22 & 60 & 224 & 1255 \\
\hline August & 7263 & 3407 & 724 & 926 & 4 & 4 & 71 & 290 \\
\hline September & 7781 & 5788 & 374 & 2052 & 5 & 25 & 88 & 29 \\
\hline October & 5311 & 3000 & 4241 & 16043 & 2802 & 5131 & 142 & 3 \\
\hline November & 1989 & 1530 & 14987 & 38464 & 2152 & 3165 & 35 & 0 \\
\hline December & 2129 & 2005 & 21551 & 47931 & 986 & 2339 & 57 & 0 \\
\hline January & 1366 & 1452 & 5855 & 38106 & 320 & 2392 & 27 & 0 \\
\hline February & 2246 & 2111 & 4615 & 36714 & 243 & 1893 & 4 & 18 \\
\hline March & 2138 & 2823 & 4327 & 29516 & 238 & 1375 & 189 & 2756 \\
\hline Mean & $\begin{array}{c}7219 . \\
75\end{array}$ & 9840.41 & 4852.33 & 18502.08 & 592.16 & 1385.58 & 252.33 & 963.83 \\
\hline $\begin{array}{l}\text { Standard } \\
\text { Deviation }\end{array}$ & $\begin{array}{c}5585 . \\
91\end{array}$ & 11213.57 & 6743.22 & 18205.72 & 930.44 & 1651.41 & 345.73 & 1251.67 \\
\hline \multirow[t]{2}{*}{$\begin{array}{l}\text { Chi- } \\
\text { Square }\end{array}$} & Value & 132 & Value & 132 & Value & 120 & Value & 108 \\
\hline & Sign. & 0.233 & Sign. & 0.233 & Sign. & 0.242 & Sign. & 0.252 \\
\hline
\end{tabular}

In 2019-2020, Highest standard deviation was recorded for Maize, i.e., 6743.22 quintals which were followed by Wheat, Jawar and Bengal Grams, which was 5585.91, 930.44 and 345.73 quintals, whereas, in 2020-2021, Highest standard deviation was recorded for Maize, i.e., 6743.22 quintals which were followed by Wheat, Jawar and Bengal Grams which was 11213.57, 1651.41 and 1251.67 quintals.

Chi-square statistics showing in the above table state that value for Wheat, Maize, Jawar and Bengal Grams was 132, 132, 120 and 108, respectively, with significant values of $0.233,0.233,0.242$ and 0.252 , respectively, for all the significant commodity values, was more than 0.05 at a $5 \%$ level of significance, which was statistical evidence to accept the null hypothesis, i.e., there was no significant difference in selected commodity arrival during the COVID-19 outbreak as compared to the previous period. So, it can be concluded that there was no significant difference in the total arrival of Wheat, Maize, Jawar and Bengal Grams in the Fathenager eNAM market during Covid-19 as compared to the previous period.

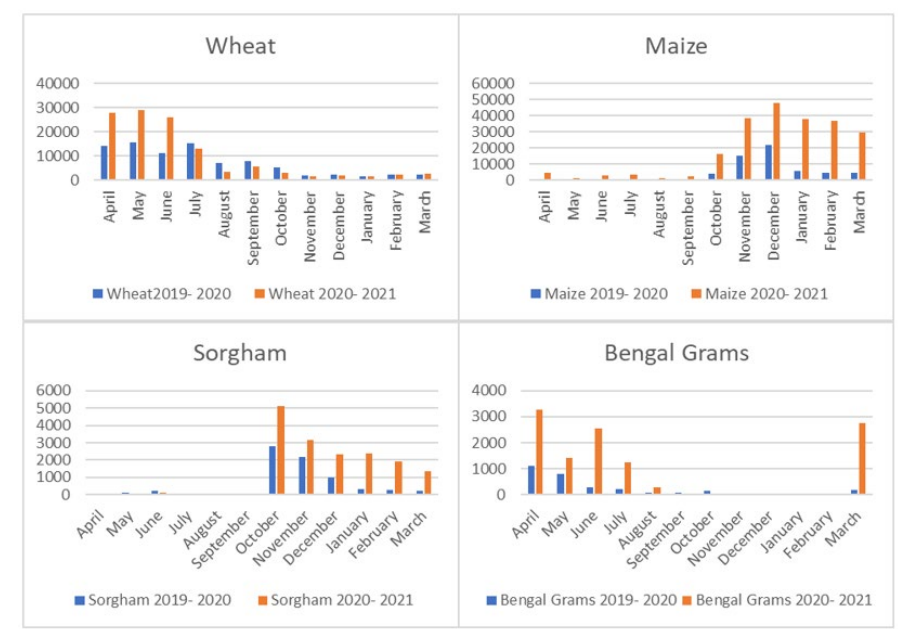

Figure 3 Showing total arrival of the selected commodity in the Fathenager Market from April to March 2021 


\section{CONCLUSIONS AND RECOMMENDATIONS}

Agriculture is the backbone of the Indian economy. As Covid-19 highly affected mostly all the sectors of the economy, but in the meantime, Indian agriculture had managed to survive even though Covid- 19 hit worst. Covid-19 is a highly contagious disease that affected almost all countries worldwide, but India has made an early move to constrain the spread of COVID-19 by imposing country lockdown. During the lockdown Government of India has announced various packages and schemes to survive and overcome Coronavirus, which includes social assistance package of INR 1.7 lakh crore. In contrast, the earlier scheme of the Central government, namely eNAM, had played a vital role in the survival of Indian agriculture during Covid-19 outbreak. eNAM had significantly increased growth with $84.8 \%$ in the last four years by integrating 1000 APMC markets with the eNAM platform. The study evaluates that Wheat, Maise, Jowar and Bengal Grams, which was the major commodity of Fathenager eNAM market, had higher total arrival during the Covid-19 pandemic than the previous period. As a result of chi-square, it was concluded that there was no significant difference in total arrival of Wheat, Maise, Jowar and Bengal Grams in the Fathenager eNAM market during Covid-19 as compared to the previous period.

\section{REFERENCES}

Arumugam, D. U., Kanagavalli, D. G., \& M, M. (2020). Covid-19: Impact of agriculture in India (SSRN Scholarly Paper ID 3600813). Social Science Research Network. Retrieved from https://papers.ssrn.com/abstract=3600813

Cariappa, A. A., Acharya, K. K., Adhav, C. A., Sendhil, R., \& Ramasundaram, P. (2021). Impact of COVID-19 on the Indian agricultural system : A 10-point strategy for post-pandemic recovery. Outlook on Agriculture, 50(1), 26-33. Retrieved from https://doi.org/10.1177/0030727021989060

Chetan, K., \& Yogesh, D. (2020, August). COVID-19 - Impacts on the Indian Agriculture. International Journal of Science and Research (IJSR), 9(8), 1188-1192. doi :10.21275/SR20822143015

Dutta, R., \& Prasad Pani, B. C. A. (2020). The coronation effect in India : The Odisha way. Journal of Global Resources, 06(si1), 64-72. Retrieved from https://doi.org/10.46587/JGR.2020.v06si01.009

Jatana, R., \& Goswami, M. (2021). An analytical study on the functioning of eNAM (With special reference to Rajasthan) (SSRN Scholarly Paper ID 3775938). Social Science Research Network. Retrieved from https://papers.ssrn.com/abstract=3775938

Kwak, S. G., \& Park, S.-H. (2019). Normality test in clinical research. Journal of Rheumatic Diseases, 26(1), 5. Retrieved from https://doi.org/10.4078/jrd.2019.26.1.5

Meera, S. N., Gandhi, R., \& Padaria, R. (2017). Accelerating impact through rice innovation systems: Integrating knowledge, technology, and markets. In The Future Rice Strategy for India (pp. 435-460). Elsevier. Retrieved from https://doi.org/10.1016/B978-0-12-805374-4.00016-6

Mittal, S. (2020). An exploratory data analysis of covid-19 in India. International Journal of Engineering Research \& Technology, 9(4). Retrieved from https://doi.org/10.17577/IJERTV9IS040550 
Nihan, S. T. (2020). Karl Pearsons chi-square tests. Educational Research and Reviews, 15(9), 575-580. $\quad$ Retrieved from https://doi.org/10.5897/ERR2019.3817

Priyadarshini, P., \& Abhilash, P. C. (2021). Agri-food systems in India : Concerns and policy recommendations for building resilience in post-COVID-19 pandemic times. Global Food Security, 29, 100537. Retrieved from https://doi.org/10.1016/j.gfs.2021.100537

Rao US, V., Rao, U., Kunigal, S. S., Kannan, S., Kumar, J., \& Gulia, A. (2021). Liveattenuated oral polio vaccine as à potential source of protection against COVID-19 - Review of the literature. Indian Journal of Medical Sciences, 73, 41-47. Retrieved from https://doi.org/10.25259/IJMS_176_2021

Sahoo, J. P., \& Samal, K. C. (2020). Impact of covid-19 on Indian agriculture. Retrieved from https://doi.org/10.13140/RG.2.2.19521.68969

Sharma, P., \& Veer, K. (2020). Action and problems related to the COVID-19 outbreak in India. Infection Control \& Hospital Epidemiology, 41(12), 1478-1479. Retrieved from https://doi.org/10.1017/ice.2020.186

Varshney, D., Kumar, A., Mishra, A. K., Rashid, S., \& Joshi, P. K. (2021). India's COVID19 social assistance package and its impact on the agriculture sector. Agricultural Systems, 189, 103049. Https : oi.org/10.1016/j.agsy.2021.103049 Retrieved from https://doi.org/10.1016/j.agsy.2021.103049

Verma, H., Mishra, V. N., \& Mathur, P. (2021). Effectiveness of lockdown to curtail the spread of Coronavirus : A mathematical model. ISA Transactions, S0019057821000355. Retrieved from https://doi.org/10.1016/j.isatra.2021.01.033 